\title{
EVALUATION OF RAINFALL-RUNOFF EROSIVITY FACTOR FOR CAMERON HIGHLANDS, PAHANG, MALAYSIA
}

\author{
Abdulkadir Taofeeq Sholagberu', Muhammad Raza UI Mustafa², \\ Khamaruzaman Wan Yusof ${ }^{2}$, Mustafa Hashim Ahmad² \\ 1 Department of Civil and Environmental Engineering, Universiti Teknologi Petronas, 32610 Seri Iskandar \\ Perak, Malaysia, e-mail: abdulkadirts4u@gmail.com \\ 2 Department of Civil and Environmental Engineering, Universiti Teknologi Petronas, 32610 Seri Iskandar, \\ Perak, Malaysia
}

Received: 2016.04 .22

Accepted: 2016.06.01

Published: 2016.07.01

\begin{abstract}
Rainfall-runoff is the active agent of soil erosion which often resulted in land degradation and water quality deterioration. Its aggressiveness to induce erosion is usually termed as rainfall erosivity index or factor (R). R-factor is one of the factors to be parameterized in the evaluation of soil loss using the Universal Soil Loss Equation and its reversed versions (USLE/RUSLE). The computation of accurate R-factor for a particular watershed requires high temporal resolution rainfall (pluviograph) data with less than 30-minutes intensities for at least $20 \mathrm{yrs}$, which is available only in a few regions of the world. As a result, various simplified models have been proposed by researchers to evaluate R-factor using readily available daily, monthly or annual precipitation data. This study is thus aimed at estimating R-factor and to establish an approximate relationship between R-factor and rainfall for subsequent usage in the estimation of soil loss in Cameron highlands watershed. The results of the analysis showed that the least and peak (critical) R-factors occurred in the months of January and April with 660.82 and $2399.18 \mathrm{MJ} \mathrm{mm} \mathrm{ha}^{-1} \mathrm{~h}^{-1}$ year $^{-1}$ respectively. Also, it was observed that erosivity power starts to increase from the month of January through April before started falling in the month of July. The monthly and annual peaks (critical periods) may be attributed to increased rainfall amount due to climate change which in turn resulted to increased aggressiveness of rains to cause erosion in the study area. The correlation coefficient of 0.985 showed that there was a strong relationship rainfall and $\mathrm{R}$-factor.
\end{abstract}

Keywords: rainfall, erosivity factor, soil erosion, USLE/RUSLE, runoff.

\section{INTRODUCTION}

Soil is one of the vital components of the natural environment that is non-renewable on a human time-scale [communication from commission to the council, 2006]. Soil erosion by water or wind has been a global threat posing significant challenges in terms of land degradation and desertification [Valentin et al., 2005], aquatic imbalance and deterioration of water quality in rivers and reservoirs. Most soils are exposed to erosion through poor agricultural practices, indiscriminate deforestation, overgrazing, forest fires hazard, land slide, construction and mining activities among others. Soil erosion has both onand off-site impacts on land and water resources. On-site impact can be degradation of soil quality due to immediate loss of its upper layer [Bakker et al., 2004], while off-site impacts resulted in increased water turbidity and pollutants, flooding, reduced crop yield, poor water quality, loss of reservoir and river capacity, which may lead to significant economic issues and environmental degradation [Quinton et al., 2001; Haygarth, 2005; Delmas et al. 2012, Oh and Jung, 2005]. In the recent past, several techniques or models have been developed and utilized to assess soil erosion by water. These models are broadly clas- 
sified into: (i) qualitative (ii) semi-empirical or semi-quantitative and (iii) quantitative (such as empirical, conceptual, and physical) models as reported in the literature [Lal, 2001a; Fullen, 2003]. The qualitative models are based on the direct observation of soil with the aid of remote sensing or aerial photo interpretation techniques [Terranova et al, 2009]. Semi-quantitative methods are employed when basic information causing erosion is not insufficiently available. While quantitative models are used to assess soil erosion by means of empirical equations derived from the superposition of its causative factors [Terranova et al, 2009] on geographic information system platform. For instance, Wischmeier and Smith [1978] analyzed soil erosion data from 8000 communities in twenty-one states in the United States and introduced the universal soil loss equation (USLE) for assessment of soil loss by water. USLE is used to predict average annual rate of erosion on long-term basis for a field slope and it involves parameterization of several factors such as rainfall erosivity factor- $\mathrm{R}$ (MJ mm ha-1 $\mathrm{h}^{-1} \mathrm{yr}^{-1}$ ), soil erodibility factor-K ( $\mathrm{t}$ ha $\mathrm{yr} \mathrm{ha}^{-1} \mathrm{MJ}^{-1} \mathrm{~mm}^{-1}$ ), slope length factor-L, slope steepness factor-S, cover and management factor-C and the supporting practices factor-P [Ming-His and Huan-Hsuan, 2015; Souyoung et al., 2011; Renard and Freimund, 1994]. A revision of the USLE model, called RUSLE [Renard et al., 1997] is widely used in temperate zones whose R-factor, is the summation of all erosive events during one year period [Wischmeier and Smith, 1978].

Rainfall is one of the active drivers of soil erosion owing to its potential for detaching soil particles and subsequent displacement. Soil loss caused by the impact of raindrop and surface runoff are often estimated using USLE/RUSLE and its termed rainfall erosivity, which quantifies the kinetic energy of raindrop and rate of surface runoff. Due to scarcity of field measurements of kinetic energy of rainfall, both in time and space, several researches have been conducted to assess the relationship between rainfall characteristics and soil detachment [Meusburger et al. 2012]. However, computation of R-factor for a particular watershed requires high temporal rainfall resolution (pluviograph) data with maximum of 30-minutes intensities for at least $20 \mathrm{yrs}$ [Meusburger et al. 2012]. But precipitation time-series with such temporal resolution is rarely available in many parts of the world. Thus, various simplified models have been proposed for estimating R-factor using precipitation volume (daily, monthly or yearly data) instead of intensity [Meusburger et al. 2012]. Thus, the present study is aimed at evaluating the temporal distribution of rainfall erosivity and to establish its relationship with precipitation in Cameron Highlands' watershed, Pahang, Malaysia

\section{MATERIALS AND METHODS}

\section{Description of study area}

The Cameron Highlands in the Peninsular Malaysia, is situated on $4^{\circ} 19^{\prime}-4^{\circ} 37^{\prime} \mathrm{N}$ and $101^{\circ} 21^{\prime}-101^{\circ} 30^{\prime} \mathrm{E}$ in a mountainous region. It is a district in the state of Pahang Malaysia with approximate total area of $712 \mathrm{~km}^{2}$ [Gasim et al., 2009] as shown in Figure 1. It is bordered by Lipis district on the South-east, Kelantan on the north and Perak on the west [Othman et al., 2010]. In its catchment, the average elevation is approximately $1,180 \mathrm{~m}$ with the highest of 2,032 $\mathrm{m}$ (above sea level) at Gunung Brinchang [IEA, 2006]. Almost twenty-five per cent of the study area is located below the elevation of $1,000 \mathrm{~m}$, while the two-thirds of the area fell within 1,100 to $1,600 \mathrm{~m}$ [Gasim et al., 2009]. Meteorological records indicated an average temperature below $25{ }^{\circ} \mathrm{C}$ and rainfall of $2,800 \mathrm{~mm}$, with western foothill areas receiving more precipitation than mountainous areas. There are three main rivers (Bertam, Telom and Lemoi Rivers) which serve as sources of water for domestic, agricultural, irrigation and hydropower generation. Sungai Bertam is the most important river flowing into the TNB Ringlet Reservoir where the Sultan Abu Bakar Dam [IEA, 2006] is situated. Two rivers, Telom and Bertam drain eastwards into the Sg. Pahang and subsequently into the South China Sea in the eastern coast of the Peninsular Malaysia [IEA, 2006].

The region is characterized as recreational and agricultural areas, in which water resources are sourced from rivers [Ranya et al., 2015]. Extensive and indiscriminate anthropogenic activities such as deforestation and land clearing in the areas for agricultural activities [Lulseged and Quang, 2015] and housing development have exposed the catchment to soil erosion [IEA, 2006]. It was reported that there was upsurge in agricultural and urban development within 1995-2003, 


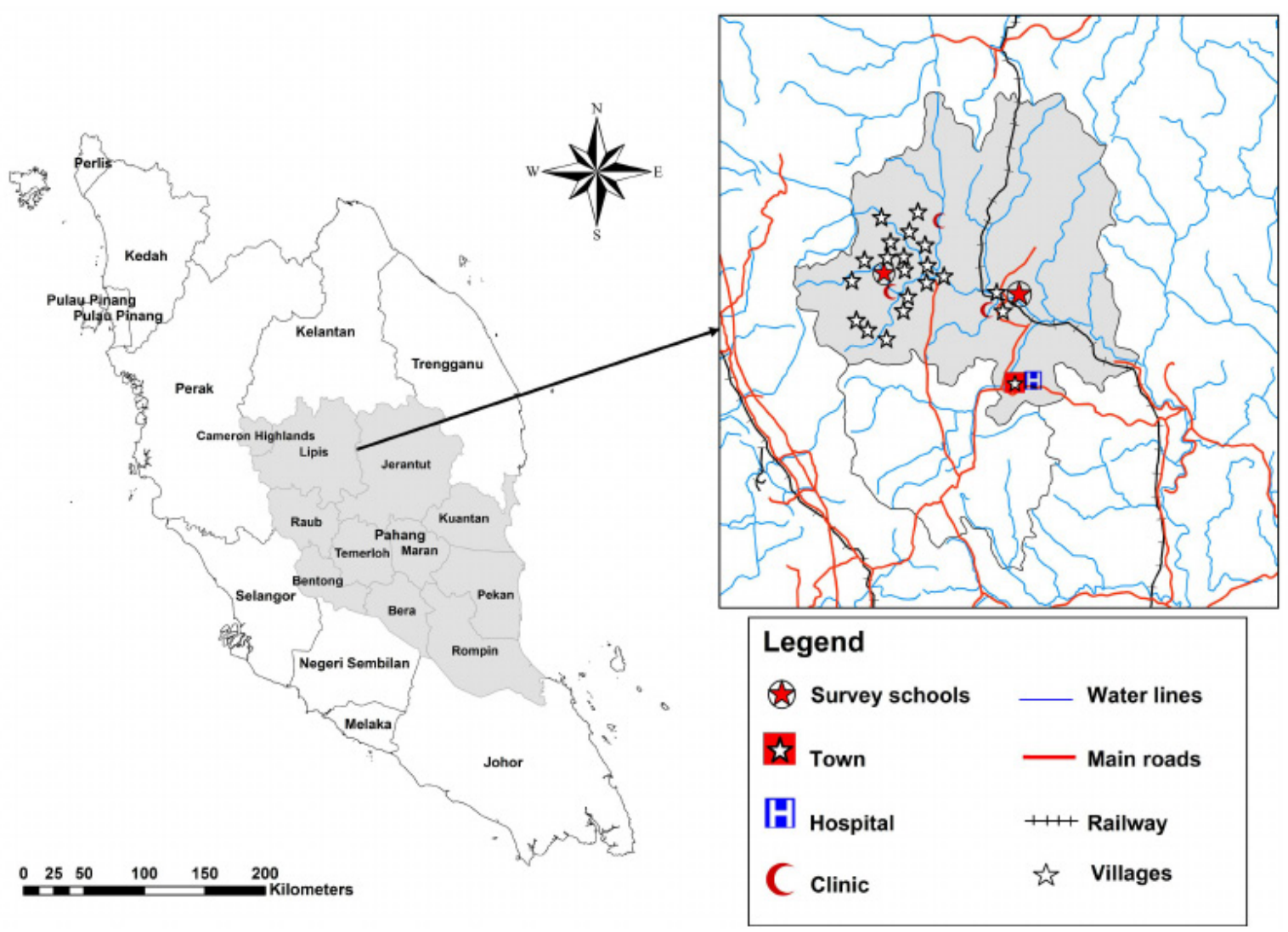

Figure 1. Map of Malaysia showing Pahang State and the watershed

from 5125 to 5671 ha for agriculture and 593 to 830 ha for urbanization [Gasim et al., 2009]. Thus it exposes the catchment to soil erosion that introduces chemical pollutants and suspended solids to the river system which deplete water quality, loss of reservoir and river capacity and negative impacts on aquatic lives, water qualities and aquatic lives [Othman et al., 2010].

\section{Universal Soil Loss Equation and R-factor}

Many studies have been carried out to improve the version of empirical USLE model since 1978 such as reversed USLE (RUSLE) [Renard et al., 1997], modified USLE (MUSLE) [Williams, 1975]. RUSLE is an empirical model used to predict average annual rate of soil erosion in watersheds for a number of scenarios involving cropping systems, management techniques and erosion control practices [Maria et al., 2008]. Both RUSLE and MUSLE are often used for estimation of surface erosion and sediment yield. In MUSLE, rainfall energy factor is replaced with a runoff factor and optimizes hydrological process of sediment yield prediction. Evaluation of soil loss using USLE/RUSLE involved parameteriza- tion of five major factors: rainfall pattern, soil type, topography, crop system, and management practices as shown in Equation 1.

$$
A=R \times K \times L \times S \times C \times P
$$

where: $A$ - temporal and spatial average soil loss per unit area $\left(\mathrm{t} / \mathrm{ha} \mathrm{year}^{-1}\right), R$ - rainfall-runoff erosivity factor, $\mathrm{MJ} \mathrm{mm} /$ (ha h year), $K$ - erodibility factor, tons ha $\mathrm{h} /($ ha $\mathrm{MJ}$ $\mathrm{mm}), L$ - slope-length-factor, $S$ - slope factor, $C-$ management factor, $\mathrm{P}-$ conservation practice factor.

Rainfall erosivity as one of the major parameters of soil erosion and is defined as the aggressiveness of the rains to induce erosion to soil [Lal, $2001 \mathrm{~b}$. It is a factor that actually triggers erosion by action of runoff and rainfall on soil surface. In the past, many studies based their own calculation of R-factors on either time series analysis of data from a single station e.g. Mikos et al. [2006] or regional approximation equation for a large spatial scale [Renard et al., 1997]. The erosivity index or factor (R) of USLE/RUSLE is considered to be the most highly correlated index to soil loss at many sites throughout the world [Aronica et al., 1997; Yu and Rosewell, 1996]. This R-factor 
is mathematically expressed as product of kinetic energy of a rainfall event and its maximum 30min intensity [Brown and Foster, 1987] as shown in Equation 2.

$$
R=\frac{1}{n} \sum_{j=1}^{n} \sum_{k=1}^{m j}\left(E I_{30}\right) k
$$

where: $R$-factor - annual average rainfall erosivity, MJmm ha ${ }^{-1} \mathrm{~h}^{-1} \mathrm{yr}^{-1}, n-$ years of records, $m j$ - number of erosive events of a year $j$, and $E I_{30}$-rainfall erosivity index of a single event $\mathrm{k}$ [Meusburger et al., 2012].

The event erosivity $E I_{30}\left(\mathrm{MJmmha}^{-1} \mathrm{~h}^{-1}\right)$ is as defined Equation 3

$$
E I=E I_{30}=\left(\sum_{r=1}^{0} e_{r} v_{r}\right) I_{30}
$$

where: $e_{r}$ - unit rainfall energy $\left(\mathrm{MJ} \mathrm{ha}^{-1} \mathrm{~mm}^{-1}\right)$, $V_{r}-$ rainfall volume in a period of $r$ time. $I_{30}$ - maximum rainfall intensity in a period of 30 min event $\left(\mathrm{mm} \mathrm{h}^{-1}\right)$.

The unit rainfall energy can be estimated for each time interval using Equation 4.

$$
e_{r}=0.29\left[1-0.72 \exp \left(-0.05 i_{r}\right]\right.
$$

where: $i_{r}$ - rainfall intensity during the time inter$\operatorname{val}\left(\mathrm{mm} \mathrm{h}^{-1}\right)$.

The criteria for the identification of an erosive event are well defined by Renard et al. [1997] as reported by [Meusburger et al., 2012] as follows: (i) cumulative rainfall of an event $>12.7 \mathrm{~mm}$, or (ii) the event has at least one peak $>6.35 \mathrm{~mm}$ in $15 \mathrm{~min}$ and (iii) a rainfall-period $<1.27 \mathrm{~mm}$ in $6 \mathrm{~h}$ is used to divide a longer rainfall period into two storm events.

\section{Some available methods}

Due to rare availability of pluviograph and detailed rainfall data in many meteorological stations across the globe, mean monthly and annual rainfall amount [Renard and Freimund, 1994] have been used for estimation of $\mathrm{R}$ factor as a function of monthly and annual mean rainfall data. Ming-Hsi and Huan-Hsuan [2015] reported that in many countries, annual rainfall time series have been utilized to estimates R-factor. Renard and Freimund [1980] proposed the use of both monthly and mean annual rainfall depths for estimation of R-factor that was previously introduced by Arnoldus [29] and modified Fournier index, F, as in Equation 5.

$$
F=\sum_{i=1}^{12} \frac{P_{i}^{2}}{P}
$$

where: $P_{i}-$ mean rainfall amount in $\mathrm{mm}$ for month $i$.

According to Arnoldus [1980], F-index is linearly correlated to R-factor. Even with seasonal variability in rainfall, Bagarello [1994] showed that the F-index is strongly linearly correlated to the annual mean rainfall. Colotti [2004] reported that the Food and Agriculture Organization (FAO) of the United Nations used the modified Fournier index as an erosion estimate according to Equation 6.

$$
R=a F+b
$$

where: $R$ - rainfall erosivity factor, $F$ - modified Fournier index (MFI), and $\mathrm{a}$ and $\mathrm{b}$ are two regional fitting parameters.

The $F_{F}$-index in Equation 7 is also correlated with the R-factor [Ferro et al., 1991] taking into consideration the distribution of actual monthly precipitation during each year $(\mathrm{Fa}, \mathrm{j})$ for a period of $\mathrm{N}$ years [Maria et al., 2008] as defined in Equation 7. Arnoldus [1980] developed an expression connecting the $\mathrm{F}$ and $\mathrm{R}$ for the United States and some regions in Africa. While some other authors correlated $\mathrm{R}$ with annual rainfall amount, MFI or summer rainfall amount. In an extensive review conducted by Morgan [1986] covering Ivory Coast and Malaysia confirmed validity of applying this kind of approach. In literature, there are several other reported expressions for estimation of R-factor such as modified Fournier index (MFI), Sicily, Arnoldus and Morocco equation, Wischmeier and Smith, etc. Arnoldus equation is as given in Equation 8.

$$
F_{F}=\sum_{j=1}^{N} \frac{F_{a . j}}{N}=\frac{1}{N} \sum_{j=1}^{N} \sum_{i=1}^{12} \frac{P_{i . j}^{2}}{P_{j}}
$$

where: $P_{i j}$ - rainfall depth in $\mathrm{month} /(\mathrm{mm})$ of the year $\mathrm{j}$ and $P$ - rainfall total for the same year [Maria et al., 2008].

$$
R=\left[4.17 * \sum_{i=1}^{12} \frac{P_{i}^{2}}{P}\right]-152
$$

where: $R$ - rainfall runoff erosive factor [MJ $\mathrm{mmha}^{-1}$ year ${ }^{-1}, P i-$ monthly average of rainfall for month $i(\mathrm{~mm})$ and $P$ - annual average of rainfall $(\mathrm{mm})$ [Khosrokhani and Pradhan, 2014]. 
Wischmeier and Smith [1978] proposed an expression in Equation 9 for estimation of R-factor using monthly rainfall data. Arnoldus approximation method called Modified Fournier Index (F') introduced a slope factor of 1.6881 $\mathrm{mm}^{-1}$ for estimation of R-factor from monthly data as in Equation 10.

$$
\begin{gathered}
R=\sum_{i=1}^{12} 1.735 * 10^{1.5 \log _{10}\left(P_{i / P)-0.08188}\right)} \\
F^{\prime}=1.6881 * \sum_{i=1}^{12} \frac{P_{i}^{2}}{P}
\end{gathered}
$$

where: the rainfall erosivity $R\left(\mathrm{MJ} \mathrm{mm} \mathrm{ha}^{-1} \mathrm{~h}^{-1}\right.$ ) and 1.6881 is the slope factor [Vandekerckhove, 2006].

In a study conducted by Bol [1978] in Indonesia generated an empirical model as show Equation (11) relating $\mathrm{R}$-factor to rainfall $\mathrm{P}(\mathrm{mm})$. This was adopted and applied to a watershed in Cameron Highlands, Pahang, Malaysia due to similarity in climatic condition [Soo, 2011].

$$
R=\frac{2.5 P^{2}}{100(0.07 P+0.73)}
$$

Several other researchers developed expressions relating R-factor to rainfall for different localities using either linear function in Hondurans [38], Italy [39] or power functions in Australia [Yu and Rosewell, 1996], US [Renard and Freimund, 1994], Taiwan [Ming-His and Huan-Hsuan, 2015]. However, several studies have shown that there is a good correlation between the annual Rfactor and the annual rainfall amount in many regions around the globe [Bonilla and Vidal, 2011].

Loureiro and Coutinho [2001] developed a new model through multiple linear regressions for estimation of RUSLE $\mathrm{EI}_{30}$ parameter using monthly rainfall data of twenty-eight years from thirty-two daily-reading of rainguage stations in Algarve region, Portugal. The model is as shown in Equation 12 which has been used in many other similar studies owing to its high predicting power.

$R=\frac{1}{N} \sum_{i=1}^{N} \sum_{m=1}^{12}\left(7.05 * \operatorname{rain}_{10}-88.92 * \text { days }_{10}\right)_{i, m}$

where: $N$ - number of record years, $\operatorname{rain}_{10}-$ monthly rainfall for days $\geq 10 \mathrm{~mm}$, otherwise set to zero, days 10 - monthly number of days with rainfall $\geq 10 \mathrm{~mm}$.
In this present study, Loureiro and Coutinho approximation approaches was applied to estimate R-factor using twenty-three (1991-2013) years of monthly rainfall data of Cameron Highlands region of Malaysia.

\section{RESULTS AND DISCUSSION}

The mean monthly or annual distribution of erosivity index (R-factor) represents the energy impact of rainfall to induce the initial removal of topmost soil layer within the vicinity of the study area. This has negative implications on agricultural and other related activities within the catchment. In this study, Loureiro and Coutinho approximation approach was employed for estimation of R-factor and regression analysis was used to establish relationship between R-factor and rainfall for the watershed in Cameron highlands, Pahang Malaysia. Monthly mean amount of rainfall was estimated from daily dataset of 23 years (1991-2013) obtained for the study area. Temporal (monthly) variability pattern of R-factor for the study area is as shown in Figure 2. This show showed that there are basically two critical periods of high R-factor (April and November) in the watershed of Cameron highlands. The peak and least R-factors estimates occurred in the months of April and January having 2399.18 and $660.82 \mathrm{MJ} \mathrm{mm} \mathrm{ha}^{-1} \mathrm{~h}^{-1}$ year ${ }^{-1}$ respectively. It was observed that the erosivity power start to increase from the month of January through April before started falling to the lowest in the month of July. Then, it started increasing again from August until it reaches another peak in November. The monthly and annual peaks (critical periods) may be attributed to temporal variability of rainfall due to climate change, which in turn resulted to increased aggressiveness of rains to cause erosion in the study area. The higher erosivity observed is caused by higher amount, intensity and kinetic

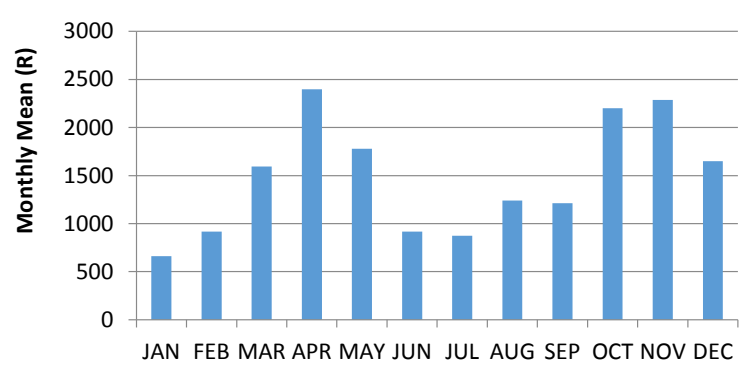

Figure 2. Monthly Temporal Variability of R-factor 
energy of the rain most especially in the tropical and temperate zones. The annual variability of $\mathrm{R}$-factors is as shown in Figure 3 with the peak occurring in year 2012. The mean annual distribution obtained in this study has minimum and maximum values of 689.12 and $1924.26 \mathrm{MJ} \mathrm{mm}$ $\mathrm{ha}^{-1} \mathrm{~h}^{-1} \mathrm{yr}^{-1}$ respectively in years 2003 and 2013.

These results are within the range when compared to the results obtained by Maria et al. [23] whose results (average annual R-factor for the period) fell within the range of 869 to $3687 \mathrm{MJ} \mathrm{mm} \mathrm{ha}^{-1} \mathrm{~h}^{-1} \mathrm{yr}^{-1}$ for a watershed at Central Crete Island, Greece. A decrease in their Rfactors obtained from locations to locations was suggested to cause due to decrease in the elevations. Due to low temporal resolution of rainfall data used in this, the rain events that actually responsible for large volume of sediment yield or soil loss cannot be identified [15]. Therefore temporal distribution R-factors throughout the year and timing of the most severe events is an important characteristic of erosivity factor [16].

A regression analysis was performed to establish a relationship between annual total rainfall (P) and annual R-factors using power function. The result of the analysis is as presented in Figure 4. While the relationship obtained for the study area is given in Equation 13 with correlation coefficient of 0.985 . This value indicted that there is a very strong relationship between the annual rainfall and $\mathrm{R}$ factor.

$$
R=0.0003 P^{1.771}
$$

\section{CONCLUSIONS}

The rainfall erosivity factor is one of the important factors in the application of USLE/RUSLE models for estimation of soil loss in watersheds. Of all the USLE/RUSLE factors/indices, erosivity factor is generally considered to be the most highly correlated index to soil loss in watershed. As a result of environmental and human activities that influences climate change and indiscriminate land use pattern, rainfall erosivity is becoming issues of great concern. This study revealed that the least and peak R-factors occurred in the months of January and April having 660.82 and 2399.18 MJ mmha ${ }^{-1}$ year ${ }^{-1}$ respectively. The erosivity power starts to increase from January through April before it started falling to the lowest in July. Then, it began to increase again from the month

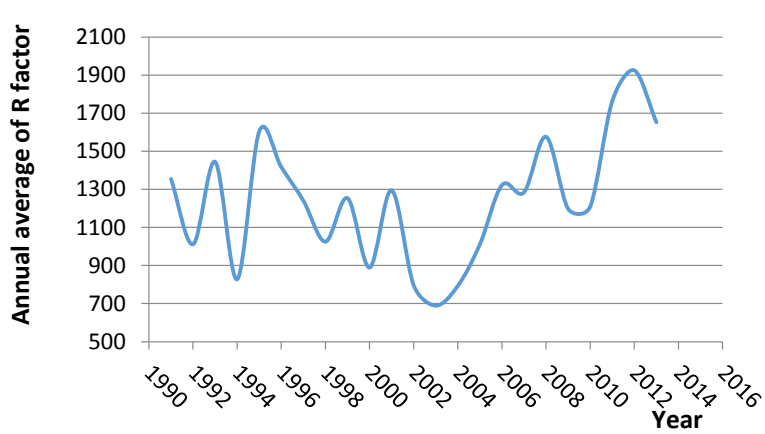

Figure 3. Annual Temporal Variability of R-factor

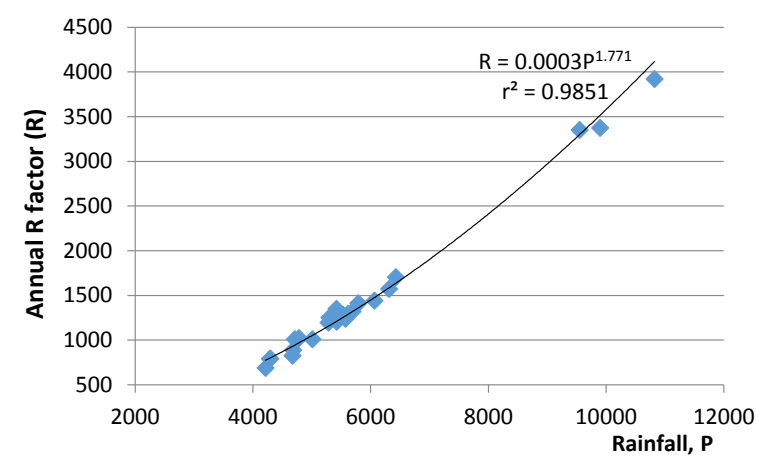

Figure 4. Relationship between annual R-factor (R) and rainfall $(\mathrm{P})$

August until it reaches another peak in the month of November. These critical periods (monthly and annual peaks) may be attributed to the effect of increased rainfall amount due to climate change, which in turn resulted in increased aggressiveness of rains to cause erosion in the study area. The results also showed that there was a very strong relationship between R-factor and rainfall. Locations having months of high erosivity index may pose a potential of ecological crisis in the area with increasing rainfall amounts, disturbances on land cover/vegetation and change in land use pattern. This may call for best hydrological monitoring in relation to climatic change in that area for best management practice of the watershed.

\section{REFERENCES}

1. Arnoldus, H.M.J.. 1980. An approximation of the Rainfall Factor in the Universal Soil Loss Equation. In M. De Boodt and D. Gabriels. (eds.). Assessment of Soil Erosion. John Wiley and Sons, Chichester, Gran Bretaña, 127-132.

2. Aronica G. and Ferro, V. 1997. Rainfall Erosivity over Calabrian region. Hydrol Sci J 42(1), 35-48,

3. Bagarello V., 1994. Procedure Semplificate per la Stima del Fattore Climatico de'lia USLE nelPam- 
biente molisano (Simplified procedures for estimating the climatic factor of the USLE in Molise, in Italian).Atti deltaGiornata diStudio SviluppiRecenti delleRicerche sull'Ewsione e sul suo Controllo, Bari, 17-18 February

4. Bakker, M.M., Govers, G., Rounsevell, M.D.A., 2004. The crop productivity-erosion relationship: an analysis based on experimental work. Catena 57 (1), 55-76.

5. Bols, P., 1978. The Is-erodent Map of Java and Madura, Belgian Technical Assistance Project ATA 105, Soil Research Institute, Bogor.

6. Bonilla C.A. and Vidal, K.L. 2011. Rainfall Erosivity in Central Chile, Journal of Hydrology, 410(1-2), 126-133.

7. Brown, L. C. and Foster, G. R. 1987. Storm Erosivity using Idealized Intensity Distributions, Transactions of the Asae, 30, 379-386.

8. Colotti, E.,. 2004. Aplicabilidad de los datos de lluvia horaria en el cálculo de la erosidad. [Applicability of hourly rainfall data to erosion analysis]. Fondo Editorial de Humanidades y Educación. Departamento de Publicaciones. Universidad Central de Venezuela, Caracas. (In Spanish).

9. Commission of the European Communities, 2006. Communication from the Commission to the Council, the European Parliament, the economic and social Committee and the Committee of the regions - Towards a Thematic Strategy for Soil Protection.

10. Delmas, M., Pak, L.T., Cerdan, O., Souchère, V. Bissonnais, Y.L., Couturier, A. and Sorel, L., 2012. Erosion and Sediment Budget Across Scale: A Case Study in a Catchment of the European Loess Belt, Journal of Hydrology 420-421, 255-263.

11. Ferro, V, Giordano, G and Iovino, M., 1991. Isoerosivity and Erosion Risk Map for Sicily, Hydro Sci. J. 36(6), 549-564

12. Fullen, M.A., 2003. Soil Erosion and Conservation in Northern Europe. Progress in Physical Geography 27 (3), 331-358,

13.Gasim, M.B., Sahid, E.T.I., Pereira, J.J. Mokhtar, M. and Abdullah, M.P., 2009. Integrated Water Resource Management and Pollution Sources in Cameron Highlands, Pahang, Malaysia, American-Eurasian J. Agric. \& Environ. Sci., 5 (6), 725-732.

14. Haygarth, P.M., 2005. Linking Landscape Sources of Phosphorus and Sediment to Ecological Impacts in Surface Waters. Sci. Total Environ. 344 (1-3), 1-3.

15. IEA, 2006. Hydropower Good Practices: Environmental Mitigation Measures and Benefits Case study 04-03: Reservoir Sedimentation - Cameron Highlands Hydroelectric Scheme, Malaysia”, Hydropower Implementing Agreement Annex VIII.
16. Khosrokhani M. and Pradhan, B. 2014. Spatiotemporal Assessment of Soil Erosion at Kuala Lumpur Metropolitan City using Remote Sensing and GIS, Geomatics Hazards and Risk, 5(3), $252-270$.

17. Lal, R., 2001a. Soil Degradation by Erosion. Land Degradation and Development 12(6), 519-539,

18. Lal R., 2001b. Soil Conservation for sequestration. In: Stott DE, Mohtar RH, Steinhardt GC (eds) Proceedings of the $10^{\text {th }}$ international soil conservation organization meeting, 24-29 May 1999, West Lafayette, 459-465.

19. Lulseged, T. and Quang, B. L., 2015. Estimating Soil Erosion in Sub-Saharan Africa Based on Landscape Similarity Mapping and Using the Revised Universal Soil Loss Equation (RUSLE)," Nutr Cycl Agroecosyst, 102, 17-31.

20. Loureiro N.S and Coutinho M.A., 2001. A New Procedure to Estimate the RUSLE $\mathrm{EI}_{30}$ index, based on Monthly Rainfall Data and Applied to the Algarve Region, Portugal, Journal of hydrology 250, 12-18.

21. Maria K, Pantelis S. and Filippos V., 2008. Soil Erosion Prediction using the Revised Universal Soil Loss Equation (RUSLE) in a GIS framework, Chania, Northwestern Crete, Greece, Environ Geol-1318-9.

22. Meusburger, K. Steel, A., Panagos, P., Montanarella, L. and Alewell C., 2012. Spatial and Temporal Variability of Rainfall Erosivity Factor for Switzerland, Hydrol. Earth Syst. Sci., 16, 167-177.

23. Ming-Hsi L. and Huan-Hsuan L. 2015. Evaluation of Annual Rainfall Erosivity Index Based on Daily, Monthly, and Annual Precipitation Data of Rainfall Station Network in Southern Taiwan, International Journal of Distributed Sensor Networks, Article ID 214708, 15 pages,

24. Mikos, M., Jost, D., and Petkovsek, G. 2006. Rainfall and Runoff Erosivity in the alpine Climate of North Slovenia: A Comparison of Different Estimation Methods, Hydrol. Sci. J., 51, 115-126.

25. Mikhailova, E.A., Bryant, R.B., Schwager, S.J. and Smith, S.D. 1997. Predicting Rainfall Erosivity in Honduras," Soil Science Society of America Journal, 61(1), 273-279.

26. Morgan R.P.C., Soil Erosion and Conservation. Longma, Essex, p. 298, 1986.

27. Oh, J.H. and Jung, S.G., 2005. Potential Soil Prediction for Land Resource Management in the $\mathrm{Na}$ kdong River basin. J. Korea Soc. Rural Plan. 11(2), 9-19.

28. Othman, J, Mohd, E. T. Shaifah-Mastura, S.A.., Muhammad, B. G., Pan, L. L., Pauszi, A., Mohd, K.A.K and Nor A.A.A., 2010. Modeling the Impact of Ringlet Reservoir on Downstream Hydrau- 
lic Capacity of Bertam River Using XPSWMM in Cameron Highlands, Malaysia”, Research Journal of Applied Sciences, 5(2), 47-53.

29. Quinton, J.N., Catt, J.A. and Hess, T.M., 2001. The Selective Removal of Phosphorus from Soil: is Event Size Important? J. Environ. Qual. 30, 538-545.

30. Ranya, F, Abdalla, E., Sarra, O. and Abdel-Rahim, E., 2015. Soil Erosion Risk Map Based on Geographic Information System and Universal Soil Loss Equation (Case Study: Terengganu, Malaysia)", Ind. J. Sci. Res. and Tech. 3(2), 38-43.

31. Renard K.G. and Freimund J.R. 1994. Using Monthly Precipitation Data to Estimate the R Factor in the Revised USLE. J Hydrol 157, 287-306.

32. Renard, K.G., Foster, G.R., and Weesies, G.A. 1997. Predicting Soil Erosion by Water; a Guide to Conservation Planning with the Revised Universal Soil Loss Equation (RUSLE), Agriculture Handbook No. 703, USDA-ARS, 404 pp.

33. Soo, H.T., 2011. Soil Erosion Modeling using RUSLE and GIS on Cameron Highlands, Malaysia for Hydropower Development, Master's thesis Submitted to School for Renewable Energy Science in affiliation with University of Iceland \& University of Akureyri.

34. Souyoung P., Cheyoung O., Seongwoo J., Huicheul $\mathrm{J}$ and Chuluong, C., 2011. Soil Erosion Risk in Korean Watersheds, Assessed using the Reversed Universal Soil Loss Equation, Journal of hydrology, 399(3-4), 263-273.
35. Terranova, O., Antronico, L., Coscarelli, R. and Iaquinta P., 2009. Soil Erosion Risk Scenarios in the Mediterranean Environment using RUSLE and GIS: An Application Model for Calabria (southern Italy), Geomorphology 112, 228-245.

36. Torri D, Booselli L, guzzetti F, Calzalari C, Bazzoffi P, Ungaoro F, Bartolini D, Salvador-Sanchis M.P, 2006. Soil Eroision in Italy: An Overview in Soil Erosion in Europe, Boardman J, Poesen J (eds) Wiley NY, 245-261.

37. Valentin C., Poesen J and Yong L. 2005. Gully Erosion: Impact, Factors and Control, Catena 63, 132-153.

38. Vandekerckhove, B. 2006. Estimation of Sediment Transport in a Watershed in an Arid Region of North Chile. MSc. Thesis. Ghent University, Belgium, $115 \mathrm{pp}$.

39. Wischmeier, W.H. and Smith, D.D., 1978. Predicting Rainfall Erosion Losses - A Guide to Conservation Planning. Agric. Handbook No. 537, Washington D.C., 58.

40. Williams, J. R., 1975. Sediment-Yield Prediction with Universal Equation Using Runoff Energy Factor. Present and Prospective Technology for Predicting Sediment Yields and Sources, ARSS-40, US Department of Agriculture, Agricultural Research Service, 244-252.

41. Yu, B. and Rosewell, C.J., 1996. An Assessment of a Daily Rainfall Erosivity Model for New South Wales. Aust J Soil Res 34, 139-152. 